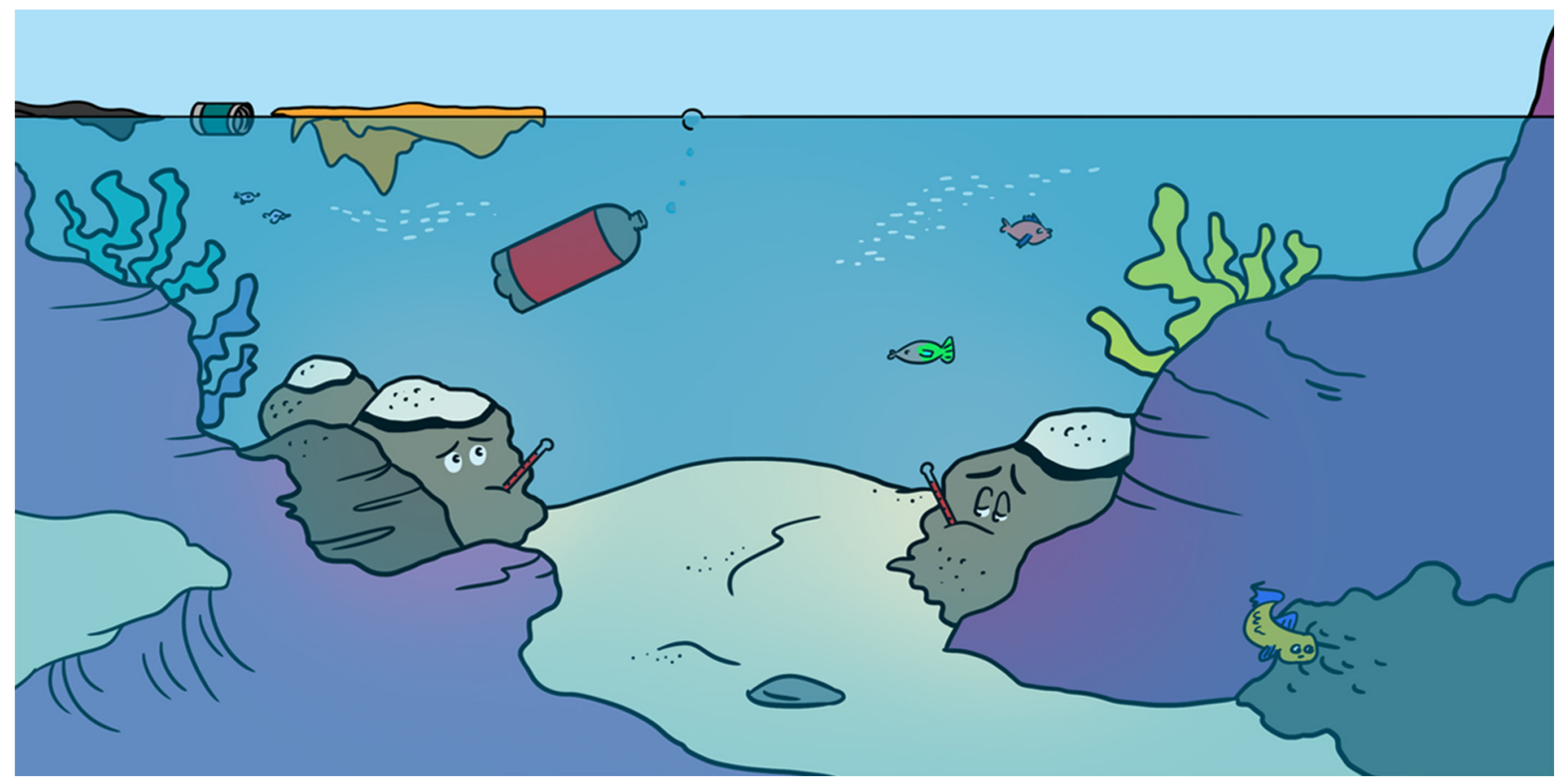

\title{
CORALS ARE SICK: BLACK BAND DISEASE IS ATTACKING
}

\section{Ghaida Hadaidi $^{1^{*}}$ and Christian R. Voolstra ${ }^{1,2}$}

${ }^{1}$ Division of Biological and Environmental Science and Engineering, Red Sea Research Center, King Abdullah University of Science and Technology, Thuwal, Saudi Arabia

${ }^{2}$ Department of Biology, University of Konstanz, Konstanz, Germany

\section{YOUNG REVIEWERS:}

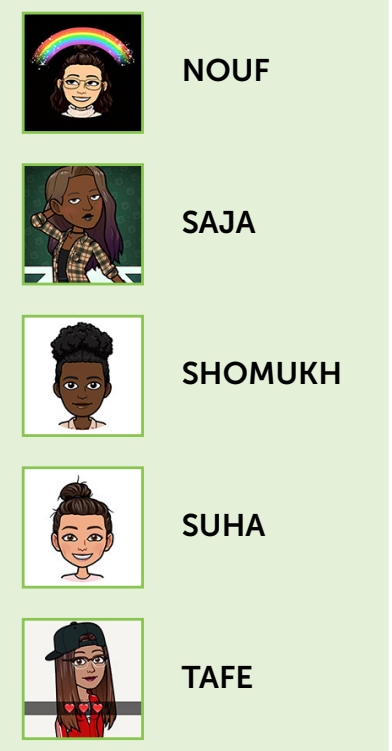

If you snorkel or dive in the Red Sea, you will see large, colorful rocks surrounded by different types of fish. These amazing structures are actually not rocks - they are animals called corals and they build coral reefs. Yes, they are animals! These animals do not live alone, instead they live with tiny plant cells inside them and many other microbes, such as bacteria and viruses. Coral animals and their friends are in danger, because the water temperature is getting higher and because humans throw their trash into the oceans. Did you know that corals can be ill and have diseases, just like human beings? Many coral diseases have been described. One of these coral diseases is called black band disease (BBD). This article will explain what BBD is, what causes it, and how we can help corals to be healthier.

\section{LIKE OTHER ANIMALS, CORALS CAN GET DISEASES}

Corals are animals that build structures called coral reefs. Corals live with other organisms, including microbes, such as tiny plant cells, 
Figure 1

A diseased coral. The healthy greenish tissue is separated from the dead white tissue by a black band full of harmful bacteria (green arrow). The black band is a sign of a coral disease called black band disease.

\section{BACTERIA}

Very small organisms that live everywhere and can be good or bad; some bacteria can cause diseases.

\section{POLYMICROBIAL}

The involvement of multiple types of microbes.

\section{SULFATE-REDUCING} BACTERIA (SRB)

A group of bacteria that "breathe" sulfur, rather than oxygen.

SULFIDE-OXIDIZING BACTERIA (SOB)

A group of bacteria that uses chemical energy to make sugars.

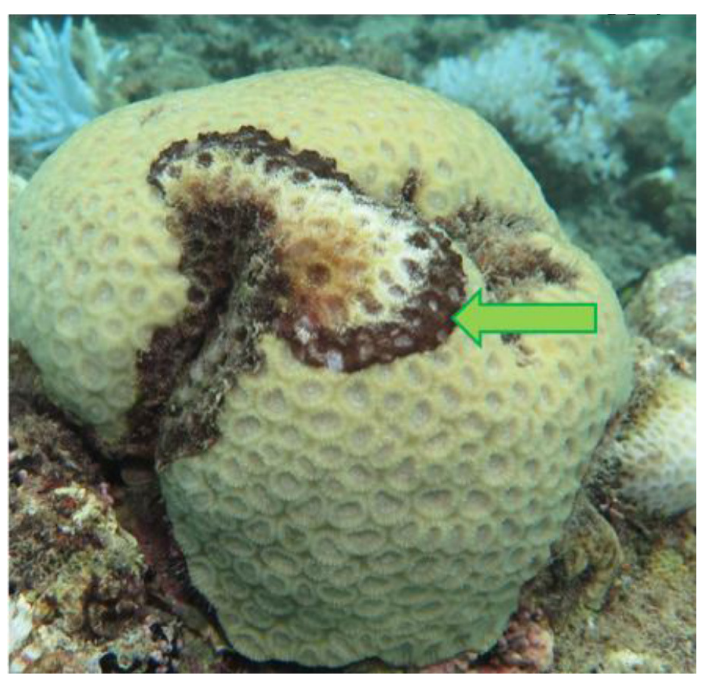

Figure 1

bacteria, and viruses. These partners all depend on each other for food and energy [1]. Unfortunately, this relationship is sensitive and can break down when the coral is stressed. If any partner is stressed, the coral will become more sensitive to diseases. Yes, like all animals, corals can be affected by diseases. Coral diseases are a consequence of changing interactions between the corals, their microbes, and environmental conditions, such as high temperatures or the presence of too many nutrients in seawater. In our study, we investigated one of the most studied coral diseases, one that is caused by a specific group of microbes. This disease is called black band disease (BBD) and it is easy to recognize, because of the visible black bands on the surface of the corals (Figure 1).

\section{WHAT IS CAUSING BBD IN THE RED SEA?}

Because it is common on coral reefs around the world, BBD is the most studied coral disease, and it was also the first to be described [2]. This disease is a serious danger to coral reefs worldwide, because it may lead to the death of corals. Previous studies have shown that the presence of BBD increases during warm summer months [3].

BBD is known as a polymicrobial disease, which means that multiple kinds of bacteria cause this disease. The three types of bacteria that have been found to cause BBD are cyanobacteria (a blue-green type of bacteria), sulfate-reducing bacteria (SRB), and sulfide-oxidizing bacteria (SOB). Like plants, cyanobacteria can use the sunlight to generate sugars and oxygen. Conversely, sulfate-reducing bacteria live in environments that are free of oxygen. Sulfide-oxidizing bacteria by comparison can use chemical energy to make sugars. When they come together, these three types of bacteria create the clear black band on the corals by producing toxic chemicals. When a coral gets sick from BBD, the black band moves across the coral's surface. This 
Figure 2

The bacterial composition of black band disease from seven diseased corals This bar chart shows the percentages of each type of bacteria (cyanobacteria, sulfate-reducing bacteria, and sulfide-oxidizing bacteria) that are present in the black bands of seven coral samples from the Red Sea. The locations from which the samples were taken are listed along the bottom of the chart. The more of a specific color you see in the bars, the more of this type of bacteria was present in the sample.

\section{DNA}

The genetic information inside an organism.

\section{SEQUENCING}

A method that determines the order of nucleotides in DNA.

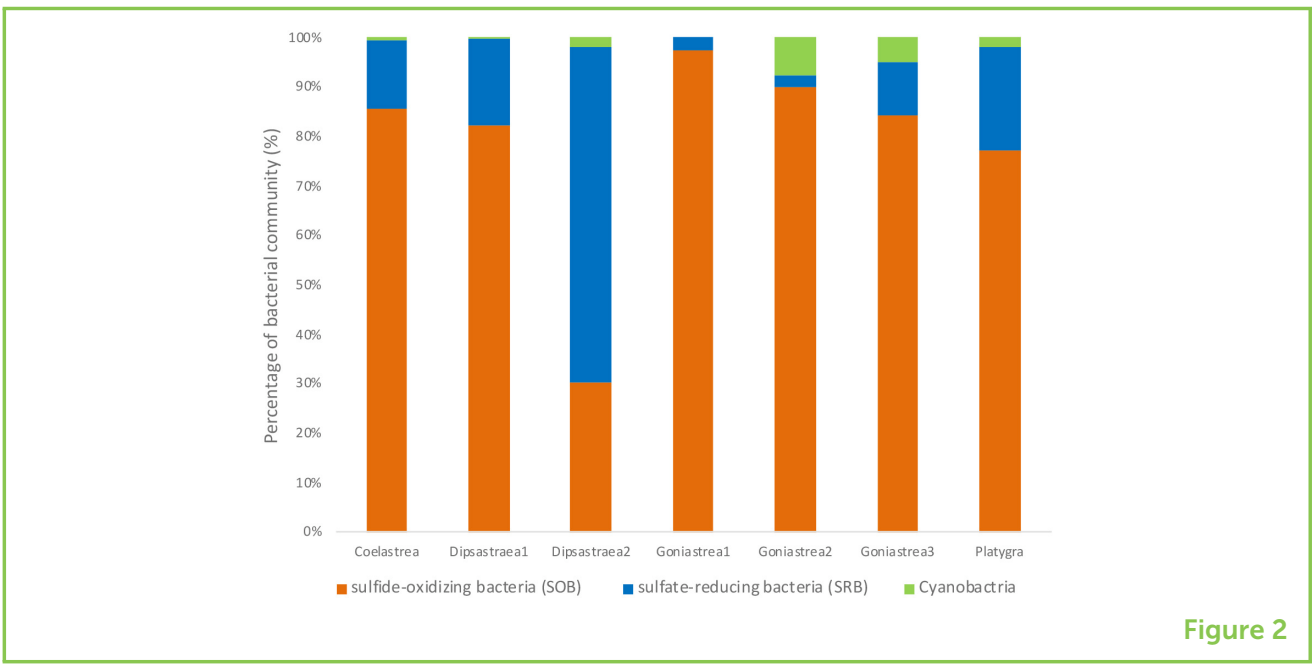

band contains toxic chemicals (sulfides) and has no oxygen, which eventually causes tissue death.

\section{DO THE SAME THREE TYPES OF BACTERIA CAUSE BBD IN THE RED SEA?}

To study BBD in corals from the Red Sea, we collected parts of the black band from the surface of different corals and transferred the samples to small tubes. To figure out which bacteria were present in the samples and to get more information about those bacteria, we analyzed the bacterial DNA. Bacterial DNA, like ours, is made from four molecules called nucleotides (A, adenine; G, guanine; C, cytosine; and $T$, thymine) that are put together in a unique order for each type of bacteria. A specific region of the bacterial DNA can serve as a barcode or fingerprint that allows scientists to distinguish different types of bacteria. Telling the types of bacteria apart is done by a process called DNA sequencing, which "reads" the order of the four DNA nucleotides present in the fingerprint region of the bacterial DNA. From there, we can look at the different sequences of the bacteria in our samples and identify which types of bacteria are present.

We found that the three main BBD-causing types of bacteria, cyanobacteria, SRBs, and SOBs, all exist in the diseased corals from the Red Sea (Figure 2) [4]. We also calculated the percentage of each type of bacteria in our coral samples (Figure 2). Finally, we compared the bacteria from BBD corals in the Red Sea to the bacteria found in BBD corals around the world and found that they were similar.

\section{PRESENCE OF BBD IN THE RED SEA}

To understand how many corals in the Red Sea are sick with BBD, we collected samples and information from 22 reefs along the coast of 
Figure 3

Coral black band disease survey sites in the Red Sea. The panel on the left shows the sea surface

temperature of the Red Sea: blue represents lower temperatures from 27 to $30^{\circ} \mathrm{C}$ and red represents higher temperatures from 32 to $35^{\circ} \mathrm{C}$ (see temperature bar on the left). As you can see, the temperature is higher in the lower, southern part of the Red Sea. The right box shows blue circles, indicating the 22 surveyed reefs along the central Red Sea coast. The survey was done from 19 October to 3 November 2015 and the temperature data is from the same time.

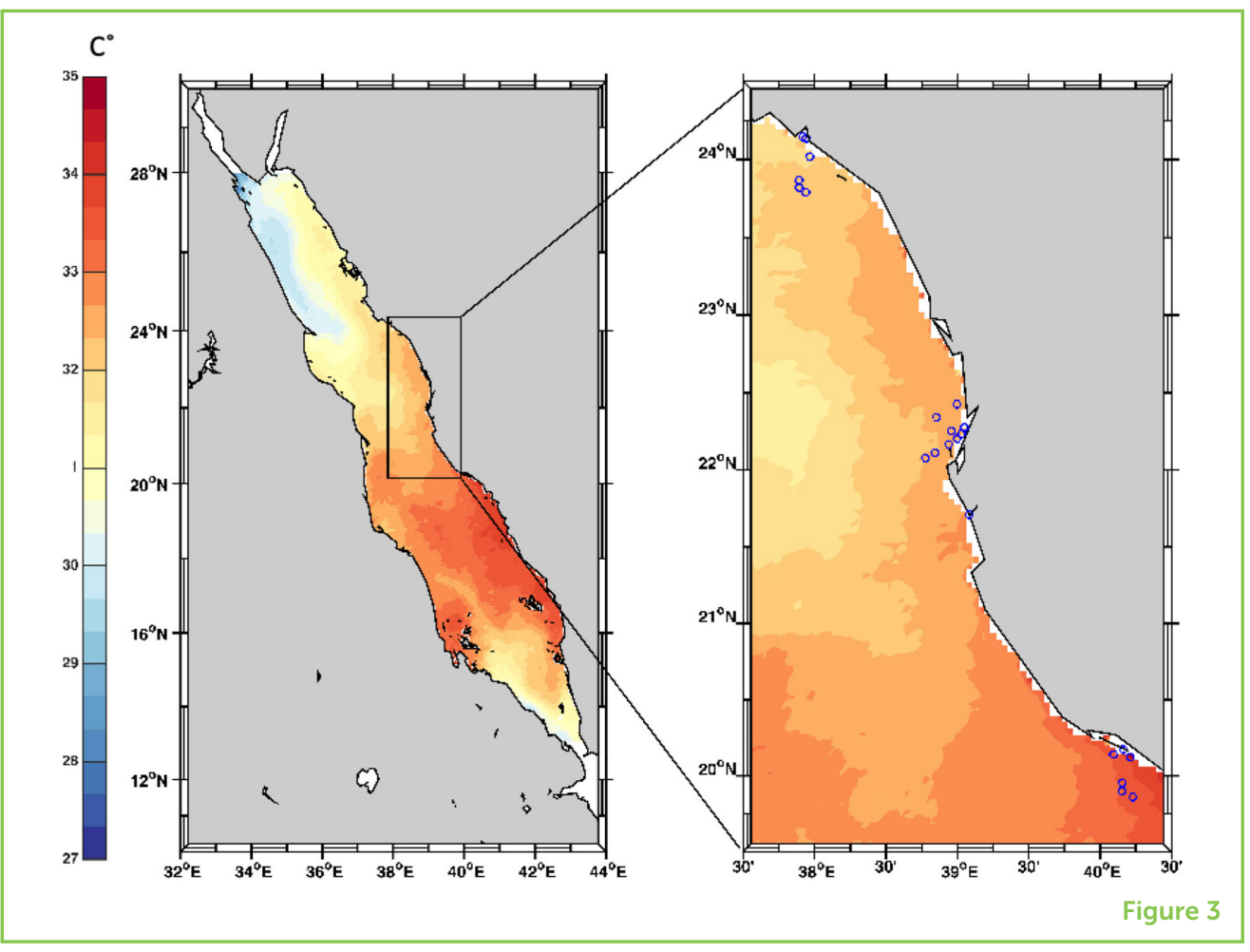

the central Red Sea (Figure 3). The occurrence of BBD was different between reefs, and only a small percentage of corals were infected. However, toward the southern part of the Red Sea, we found a reef with many diseased corals, and we were interested in why there was so much BBD at this site. After looking into the surrounding environment, the higher incidence of BBD at this site might have been related to the high seawater temperature around this reef and the trash that humans throw into the sea. So, our results and the results of other research groups suggest that keeping the ocean clean helps corals be stronger to fight off diseases.

\section{CONCLUSION}

This article describes an investigation into black band disease of different coral reefs in the central Red Sea. Our results suggest that BBD in the Red Sea seems to be caused by interactions of the same three bacterial groups that cause BBD in other reefs across the world. Although the presence of this disease is overall rare, harmful environmental conditions, such as high seawater temperature and water pollution, makes coral more susceptible to disease. In conclusion, clean oceans make for healthier corals.

\section{ORIGINAL SOURCE ARTICLE}

Hadaidi, G., Ziegler, M., Shore-Maggio, A., Jensen, T., Aeby, G., and Voolstra, C. R. 2018. Ecological and molecular characterization of a 
coral black band disease outbreak in the Red Sea during a bleaching event. PeerJ 6:e5169. doi: 10.7717/peerj.5169

\section{REFERENCES}

1. Rosenberg, E., Koren, O., Reshef, L., Efrony, R., and Zilber-Rosenberg, I. 2007. The role of microorganisms in coral health, disease and evolution. Nat. Rev. Micro. 5:355-62. doi: 10.1038/nrmicro1635

2. Richardson, L. L. 2004. "Black band disease," in Coral Health and Disease, eds E. Rosenberg and Y. Loya (Berlin; Heidelberg: Springer Berlin Heidelberg). p. 325-36.

3. Richardson, L. L., and Kuta, K. G. 2003. Ecological physiology of the black band disease cyanobacterium Phormidium corallyticum. FEMS Microbiol. Ecol. 43:287-98. doi: 10.1016/S0168-6496(03)00025-4

4. Hadaidi, G., Ziegler, M., Shore-Maggio, A., Jensen, T., Aeby, G., and Voolstra, C. R. 2018. Ecological and molecular characterization of a coral black band disease outbreak in the Red Sea during a bleaching event. PeerJ 6:e5169. doi: 10.7717/peerj.5169

SUBMITTED: 13 July 2019; ACCEPTED: 20 January 2020; PUBLISHED ONLINE: 12 February 2020.

EDITED BY: Rúben Martins Costa, King Abdullah University of Science and Technology, Saudi Arabia

CITATION: Hadaidi G and Voolstra CR (2020) Corals Are Sick: Black Band Disease Is Attacking. Front. Young Minds 8:6. doi: 10.3389/frym.2020.00006

CONFLICT OF INTEREST: The authors declare that the research was conducted in the absence of any commercial or financial relationships that could be construed as a potential conflict of interest.

COPYRIGHT @ 2020 Hadaidi and Voolstra. This is an open-access article distributed under the terms of the Creative Commons Attribution License (CC BY). The use, distribution or reproduction in other forums is permitted, provided the original author(s) and the copyright owner(s) are credited and that the original publication in this journal is cited, in accordance with accepted academic practice. No use, distribution or reproduction is permitted which does not comply with these terms.

\section{YOUNG REVIEWERS}

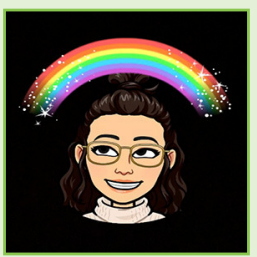

\section{NOUF}

I am someone who is interested in spreading awareness when it comes to our environment, specially our oceans. I find sharks cute. 


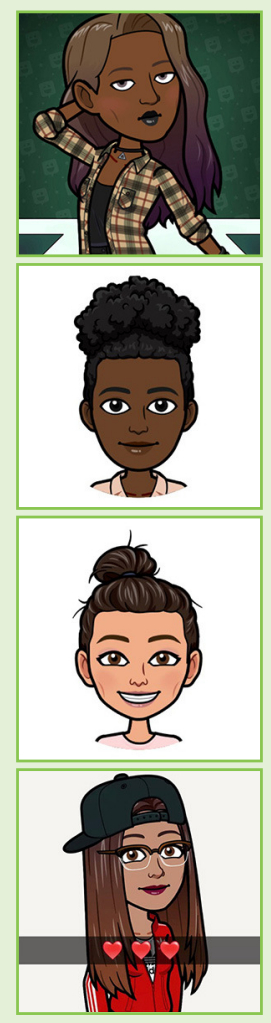

\section{SAJA}

I love Biology but specialized in computer sciences. Tupac's verses mean a lot to me. I am not an outgoing person but easy to make friends. The color white always makes me feel comfortable. I am trying to learn how to play guitar.

\section{SHOMUKH}

I am a person who loves to be at home and who is interested in learning about biology and biochemistry. I also love coloring and drawing.

\section{SUHA}

I love life, freedom, my mum, and all things girly!

\section{TAFE}

I am a very simple person. I love the sea, my favorite colors are yellow and black, and when I am bored, I like to cook! Love listening to music when I work, love to dance, and do not like waiting... I like experimenting with new things.

\section{AUTHORS}
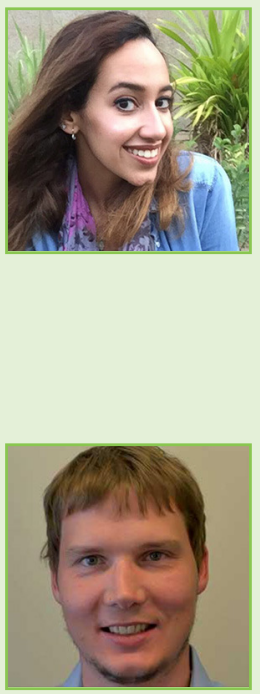

\section{GHAIDA HADAIDI}

I am a scientist and I used to work in the Reef Genomics lab at King Abdullah University of Science and Technology. I was interested in exploring coral reefs in the Red Sea and how extreme environmental factors affect their life. Seeing these spectacular creatures threatened made me write this article and share it with young kids. This article was part of my Ph.D. project where I aimed to study the role of microbial community under natural environmental stressors in the Red Sea. *ghaida.hadaidiakaust.edu.sa.

\section{CHRISTIAN R. VOOLSTRA}

I started out studying the development of fruit flies and how the house mouse adjusts to different environments, before diving into coral biology. Nowadays, I and many other researchers with me, are beginning to understand that all animals and plants team up with tiny living organisms, so-called microbes or bacteria, to digest food, stay healthy, and fight stress. In my lab, we study the different types of bacteria that live with corals and how they help their animal host to survive under stress. christian.voolstra@uni-konstanz.de 